UDC 378.147

\title{
CONTENT OF TEACHING PROFESSIONALLY ORIENTED WRITTEN COMMUNICATION
}

\author{
I. I. Antonenko \\ Kyiv, National Technical University of Ukraine "Kyiv Polytechnic Institute" \\ orchid71@mail.ru
}

The article is devoted to the problems of teaching foreign languages in non-linguistic universities in the process of professional education. Special attention is paid to teaching professionally oriented written communication in English and developing professional communicative competence of students, defining components in the system of teaching foreign languages for professional communication, content and objectives of teaching foreign languages to future specialists in the publishing and printing industry. This article examines the genre and cognitive-communicative approaches, analyzes the notions of genre and genre competence and defines their place in the methodology of teaching writing. It stresses the importance to motivate students and to create favorable learning conditions for mastering educational and professional material and to encourage intellectual development and creativity of students. The usefulness of genre approach in teaching students and in the selection of materials for teaching writing in English is explained. The groups of genres that are typical for written communication of future specialists and the classification of genres of the periodical press are analyzed.

Key words: professional education, content of teaching, professionally-oriented written communication, genre approach, genre competence.

Introduction. Globalization of the world economy requires professionals in various areas to communicate effectively in foreign languages. The success depends on the ability to manage languages and cultural barriers that is the reason why it is necessary to develop specialists' language skills and competence with respect to their professional areas. Nowadays English dominates in the world education, in media, in technology, in business and that is why the demand for English for special purposes grows rapidly.

The university curriculum in the publishing and printing industry is aimed at training an intelligent and qualified professional. The implementation of new educational goals is impossible without progress of professional competence, an important component of which is the development of foreign language professionally oriented communication, in both oral and written forms.

Aims and tasks. Teaching foreign languages to non-linguist students is a difficult task. The relevance of the topic is determined by the fact that students do not often have well-developed skills in professionally oriented written communication, and an important issue is to search and to select educational material which is the basis of the content of teaching English language for special purposes. The study is focused on learners' professional linguistic needs, as well as approaches for selecting teaching materials. Properly selected material helps to motivate students, to create favorable learning conditions and to encourage intellectual development and creativity in students.

The content of teaching English for specific purposes (ESP) is particularly important. The main aim of the article is to define components of the system of teaching foreign languages for professional communication, content and objectives of teaching foreign languages to future specialists in the publishing and printing industry, thus increasing the level in foreign language proficiency of students of publishing and printing professions. Special attention is devoted to educational qualification characteristics and educational and professional programs, training programs for all the special vocational-oriented disciplines.

The content of teaching language. The content of teaching language was investigated by I. Lerner, B. Lapidus, O. Bihych, I Bim, M. Skatkin, S. Nikolaeva, N. Gez, V. Krayevsky, O. Mirolubov and others. Modern scientists consider the content as a category, which is constantly developing and depends on the social order. They claim that the content of teaching a foreign language is a multi-component structure, the main component of which is represented by an organized educational material, which is formed and implemented in the process of learning. We should consider relevant goals and tasks of this process, whose main aspects are education and personality development. The content is determined as a system of scientific knowledge, abilities and skills, mastering of which provides comprehensive development of students' abilities, the 
formation of their world outlook and preparation for public life and work. The first task of our research is to define the structural components of ESP teaching content for students of publishing and printing professions.

According to the scientist G. Skurativska, the learning content should be adopted by personality on four levels of knowledge: skills, experience, experience of creativity and experience of emotional and value attitude to reality.

S. Nikolaeva identifies the following structural components of the content: 1) areas of communication, topics, speech situations; 2) language material, speech material, cultural and linguistic material; 3) knowledge, skills and abilities of speech.

By O. Pinska, the learning content of professionally oriented written communication consists of the following components: 1) professionally oriented fields of written communication; 2) language and speech material; 3) skills and abilities for the implementation of professionally oriented written communication.

Based on the experience of the scientist O. Synekop, who studied the characteristics of the professionally oriented writing, we will use such components of the content: 1) areas of communication, topics, speech situation; 2) language; 3) speech material; 4) country research and linguistic knowledge; 5) language skills 6) ability of writing; 7) the ability to select and process information [4].

Professionally oriented writing in a foreign language is an important form of speech activity, which students should possess according to program requirements. It is considered that modern professionally oriented approach to the teaching of foreign languages involves the formation of students' foreign language communication competence and the ability to write and communicate in a specific professional, scientific, business spheres and situations considering the features of professional thinking. Considerable success is achieved in the field of teaching ESP, which is evidenced from the works of V. Bebykh, O. Bykonya, T. Kameneva, Z. Korneva, L. Kurylo, O. Malyuga, O. Pinska, I. Simkova, G. Skurativska, I. Vereitina, E. Vasylyeva, N. Zinukova, S. Kozhushko, O. Tarnopolsky, O. Ustymenko, but they do not exhaust all issues of professional training of students of non-linguistic higher educational institutions and do not reveal the problems of foreign language training of students of publishing and printing specialties.

The content of foreign language teaching should ensure the achievement of the main goal to learn to communicate in a foreign language in oral and written forms within the acquired program material that is aimed at the formation of professional knowledge and the ability to compare, analyze, classify and organize the information. Effective learning depends on the organisation of education process, methodological quality of teaching materials and professional skills of teachers. Future professionals need to acquire the skills of foreign language communicative competence, which is considered to be formed if the student uses a foreign language for getting and expanding knowledge.

Communicative competence. Communicative competence is required by journalists, advertisers, editors for performing complex professional tasks in the conditions of informational diversity and to establish international connections with the purpose of development of professional / business contacts and to exchange experience with foreign partners. S. Kolomiets emphasizes that joint activities with foreign specialist may be in the form of direct organizational ties or exchange of experience or mutual information with scientific, technical and industrial development prospects. Also it is important to emphasize pre-contractual work on the development of the project and the direct economic relations, the creation of joint ventures [2].

After O. Tarnopolsky and Z. Korneva, we consider that it is important to form linguistic competence, psychological competence, sociolinguistic competence, subject competence, pragmatic competence (the ability to produce texts and understand speech and written communication according to their own goals and intentions, relationships) in teaching English language for special purposes the students of publishing and printing professions.

Studying written communication, T. Kameneva affirms that communication in the field of professional activity is a staged process, aimed at formation of the coherent system of collective actions, where each stage of the process is correlated with a certain level of joint activity [1].

For future professionals in public relations, employees of advertising agencies, journalists and editors, knowledge of the English language is considered as an important component of 
preparation for professional activity, which involves participation in negotiations, exhibitions and conferences, writing articles and messages for media, brochures and booklets. Future professionals ought to be able to analyze competitors' works and maintain correspondence and documentation in a foreign language. Developing communicative competence in professionally oriented writing in non-linguistic higher institutions has acquired particular attention today for several reasons. First, experts who are able to produce written texts for professional activities are strongly needed. In addition, writing skills are essential for the participation in research work. Finally, they facilitate social communication within professional community.

The formation of genre competence. Training programs of the major disciplines that the editors and advertisers study reveal some common features. One of them is aimed to introduce the system of newspaper and magazine genres, which involves the formation of genre competence, namely, the knowledge of communicative goals, macro-structures and linguistic features of the genres of texts, and the ability to produce their own texts and also provide the opportunity to develop linguistic skills in writing.

L. Shevnina believes that the genre approach is one of the important varieties of cognitive and communicative approaches. It determines the required genres, the sequence of methodical work with them and mastering different strategies and ways of creating texts of different types [5]. The formation of genre competence is revealed in the ability to comply with the communicative standards of objective reflection of the situation content, the use of speech samples, phrases, steady expressions, terms, information. The genre approach provides the ability to simulate situations of professional communication and to use professional texts, which promotes the development of genre competence of specialists. It is believed that the genre is determined by special features and traits and characteristics in composition and structure, imaginative means and creative techniques, language and style of presentation and the basis to solve any creative task.

It is necessary to know the criteria of the text attribution to one or to another genre of classical classification. Everyone who is studying journalism, examines the system of genres, because, not having mastered the genre types are not possible to achieve a level of professionalism [3].

In the classification of genre division, we will rely on the research of I. Mikhailin, A. Tertychny, V. Voroshilov, V. Zdorovega, G. Nazarenko and others who classify them into informational and analytical. Informational genres are those in which news messages dominate. These genres offer data, facts, and other types of information, without recommendations or analysis. The purpose of these genres is not only to inform the reader, viewer or listener about the fact that interests him about the event that occurred, but also to reveal it, to show the essence and main matters of it. Informational genres include: memo, report, reportage and interview. The informational texts are characterized by an interest to the fact. In periodicals texts of this kind are the main carriers of the operational information, allowing the audience to know about the most significant and interesting events in different spheres.

Analytical genres offer both information and analysis, and they can also include recommendations, the study, analysis and comment on facts. The features of these genres are: selection or printed news of important public events, prompt submission of it in the authentic message in reliable communication and writing comments, subjective evaluations and analysis. Analytical genres include such genres as correspondence, article, review and survey. Signs of analytical genres are: establishing uniformity of facts and combining them in a logical series; generalizations of them, comparisons with other, the connection between them; an assessment of the situation and phenomena; setting the problem and identifying all its aspects; suggesting ideas about their vision of the solution.

Analytical genres reveal the connection between the phenomena, give them a social assessment but rather on the analysis, research work, interpretation of events, processes, situations that occur. These genres are based on the understanding of the problem, the main thing is the ability to consider, to analyze, to find the appropriate arguments. The author involves the readers in the process of thinking, influencing their beliefs in the correctness of the author's position. Apart from genre approach, texts for teaching writing should be chosen from the point of view of the content, educational and cognitive value, availability, communicative and professional significance. 
Conclusion. Developing communicative competence in professionally oriented writing in non-linguistic higher institutions should be based on scientifically grounded and practically tested criteria for selecting teaching material of language content. We can affirm that genre approach is one of the most effective for the selection of texts for teaching foreign languages to future specialists in the publishing and printing industry. Developing selection criteria of the English texts for teaching professionally oriented writing as well as creating a system of exercises for formation and developing skills and abilities in writing is the prospect of our future research.

\section{REFERENCES}

1. Каменєва Т. М. Ефективність навчання майбутніх менеджерів писемного ділового спілкування англійською мовою з використанням електронного підручника / Т. М. Каменєва // Вісник КНЛУ. Серія „Педагогіка та психологія”. - К.: Видавництво КНЛУ, 2007. - Вип. 13. - С. 65-74.

2. Коломиец С.С. Обучение специалистов профессионально-ориентированному общению с зарубежными партнерами (на материале английского языка): дис. ... канд. пед. наук : 13.00.02 / Коломиец Светлана Семеновна. - К., 1994. - 252 с.

3. Михайлин І. Л. Основи журналістики. Підручник. 5-те вид. перероб. та доп / І. Л. Михайлин.- К.: Центр учбової літератури, $2011-496 \mathrm{c}$.

4. Синекоп О. С. Методика інтерактивного навчання англійського писемного мовлення майбутніх фахівців з інформаційної безпеки з використанням комп'ютерних технологій : дис. ... кандидата пед. наук : 13.00.02 / Синекоп Оксана Степанівна. - К., 2011. - 370с.

5. Шевніна Л. С. Формування жанрової компетенції в англійському діловому писемному мовленні майбутніх менеджерів туризму: автореф. дис. на здобуття наук. Ступеня канд.пед.наук: спец.13.00.02 / Л. Є. Шевніна. - Одеса, 2012. - 21 с.

\section{REFERENCES}

1. Kamenieva, T. M. (2007). Effectiveness of training future managers of written business communication in English with the use of the electronic textbook. Visnyk KNLU. Seriia „Pedahohika ta psykholohiia”, 13, 65-74 [in Ukrainian].

2. Kolomiec, S.S. (1994). Training of specialists professionally oriented communication with foreign partners (English language). (Unpublished candidate dissertation). Kyiv, Ukraine: Kyiv State Linguistic University [in Russian].

3. Mykhailyn, I. L. (2011). Fundamentals of journalism. (5th ed.). Kyiv, Ukraine: Centr uchbovoyi literatury' [in Ukrainian].

4. Synekop, O. S. (2011). Methodology of Interactive Teaching English Writing with the Use of Information Technologies Future Information Security Specialists (Unpublished candidate dissertation). Kyiv, Ukraine: Kyiv National Linguistic University [in Ukrainian].

5. Shevnina, L. Ye. (2012). The formation of genre competence in business English writing of future tour managers. (Unpublished candidate dissertation). Odessa, Ukraine: PUNPU. [in Ukrainian].

\section{I. І. Антоненко. Зміст навчання професійно орієнтованого писемного мовлення.}

Стаття присвячена проблемі навчання іноземним мовам студентів немовних вузів і проблемі професійної освіти фахівця, досліджується мета та зміст оволодіння англомовним писемним мовленням при навчанні студентів англійської мови. Особлива увага приділяється навчанню професійно-орієнтованого писемного спілкування іноземною мовою та формуванню у студентів іншомовної професійно-спрямованої комунікативної компетенції, компонентам системи навчання іноземної мови професійного спрямування, визначенню змісту і мети навчання іноземної мови у немовному вузі, процесу професійної підготовки спеціалістів видавничо-поліграфічної галузі спрямовано на підготовку інтелектуального та кваліфікованого фахівця. У статті досліджується жанровий підхід як різновид когнітивно-комунікативного підходу, такі поняття жанрового підходу як жанр та жанрова компетенція, визначається їх місце у методиці навчання писемного мовлення. Обгрунтовується доцільність використання жанрового підходу у навчанні студентів та у відборі матеріалів для навчання писемного мовлення англійською мовою.

Ключові слова: професійна освіта фахівця, зміст навчання, професійно-орієнтоване писемне спілкування, жанровий підхід, жанрова компетенція.

И. И. Антоненко. Содержание обучения профессионально ориентированной письменной речи.

Статья посвящена проблемам обучения иностранным языкам студентов нелингвистических вузов и профессиональному образованию специалиста. Определенное внимание уделяется обучению профессиональноориентированному письменному общению на иностранном языке и формированию у студентов профессиональнонаправленной коммуникативной компетенции, компонентам системы обучения иностранному языку профессиональной направленности, содержанию и целям обучения языку в неязыковом вузе, процессу профессиональной подготовки специалистов издательско-полиграфической отрясли, которое направлено на подготовку интеллектуального и квалифицированного специалиста. Рассматриваются жанровый и коммуникативный подход, и такие понятия жанрового подхода как жанр и жанровая компетенция, определяется их место в методике обучения письменной речи. Обосновывается целесообразность использования жанрового подхода в обучении студентов и в отборе материалов для обучения письменной речи на английском языке.

Ключевые слова: профессиональное образование специалиста, содержание обучения, профессионально-ориентированное письменное общение, жанровый подход, жанровая компетенция. 